\title{
Impact of Covid-19 and relevance of Social Thoughts of Mahatma Gandhi
}

\author{
Anil Prakash Shrivastava ${ }^{1}$, Dr. Jyotsna Agarwal ${ }^{2}$, Dr. Ajay Kumar Ghosh ${ }^{3}$
}

${ }^{1}$ Research Scholar 'Department of History', Barkatullah University, Bhopal, MP, India,
${ }^{2}$ Professor, Govt. Sarojini Naidu Girls P.G. Autonomous College Bhopal Madhya Pradesh,
${ }^{3}$ Professor, Govt. Hamidiya Arts and Commerce College Bhopal, Madhya Pradesh

Received: 03 Oct 2021; Received in revised form: 09 Nov 2021; Accepted: 21 Nov 2021; Available online: 27 Nov 2021 (C)2021 The Author(s). Published by Infogain Publication. This is an open access article under the CC BY license (https://creativecommons.org/licenses/by/4.0/).

\begin{abstract}
We are facing a global crisis unlike any in the world since last century. The outbreak of Covid19 pandemic has affected the entire human social-economic life and all segments of the population. Evidences shows that besides impact on health and economy, it has adversely affected the social infrastructure, values and practices within the society. A huge social crisis of unemployment and migration of poor and middle-class workers has emerged both from Pandemic and its aftermath. The common man, including people living in poverty situations, older persons, persons with disabilities, youth, and indigenous peoples has been affected badly.

In this challenging situation, Gandhi's social thoughts and his philosophy have become very useful today. Gandhi believed in the unity of human life, which is a synthetic whole. There can be no problems that are purely moral, economic, political, social, individual or collective. They are inextricably intertwined. Gandhi always dreamed and made efforts for economic transformation through social change. Thus, what is needed today is commitment to action on a massive scale, to make opportunities equally good for all. And whatever action is proposed it must be in the Gandhian way, an exercise of moral force. Implementation of the concept of 'Atmanirbhar Bharat' is the real Gandhian way of moving forward in this direction. It's an attempt to increase self-reliance in social life by promoting 'Vocal for Local' and 'Local for Global'. In fact, Gandhi has advocated for a system, in which despite of social diversity, the society should act and grow together. He introduced The Constructive Programme as blueprint for the social regeneration of India, Gandhi felt that real progress of India lies in its villages. He wanted the youth to make village life their goal, which has its roots in the ancient civilization of India. Gandhi especially called upon the youth to undertake the task for they are the real torchbearers of the future, in whose hands India had great future and this is actually need of the hour today.
\end{abstract}

This paper is an attempt to examine the social thoughts and ideas of Mahatma Gandhi and discuss their relevance in situation apparent during and after covid-19.

Keywords - Covid-19, Impact of Covid, Mahatma Gandhi, Pendamic, Social Thoughts.

\section{INTRODUCTION}

The outbreak of Covid-19 pandemic has affected the entire human social-economic life and all segments of the population. Evidences shows that besides impact on health and economy, it has adversely affected the social infrastructure, values and practices within the society. It has led to a lot of rethinking about socio-economic framework that we have woven around us and its consequences during normal as well as abnormal times. A huge social crisis of unemployment and migration of poor and middle-class workers has emerged both from Pandemic and its aftermath. In this challenging situation, 
Gandhi's social thoughts and his philosophy have become very useful today. Gandhi believed in the unity of human life, which is a synthetic whole.

\section{ABOUT COVID-19}

The Covid-19 spread through Noval Corona virus, which is named after SARS-CoV-2, or Severe Acute Respiratory Syndrome Coronavirus 2. Coronavirus disease (COVID19) is an infectious disease caused by the SARS-CoV-2 virus. On March 11, 2020, the World Health Organization declared COVID-19 a global pandemic, indicating significant global spread of an infectious disease. At that point, there were 118,000 confirmed cases of the coronavirus in 110 countries. China had been the first country with a widespread outbreak in January, and South Korea, Iran and Italy following in February with their own outbreaks. Soon, the virus was spread in all continents and over 177 countries, including, the United States has the highest number of confirmed cases and, sadly, the most deaths. The virus was extremely contagious and led to death in the most vulnerable, particularly those older than 60 and those with underlying conditions. The most critical cases led to an overwhelming number being admitted into the intensive care units of hospitals, leading to a concern that the virus would overwhelm local health care systems. In early May 2020, there have been nearly 250,000 deaths worldwide, with over 3,500,000 confirmed cases. The human toll is staggering, and experts are predicting a third wave after second wave which was struck in March -April 2021.

The virus of SARS-CoV-2 can spread from an infected person's mouth or nose in small liquid particles when they cough, sneeze, speak, sing or breathe. These particles range from larger respiratory droplets to smaller aerosols. It is important to practice respiratory etiquette, for example by coughing into a flexed elbow, and to stay home and self-isolate until you recover if you feel unwell. The only historical memory of a similar pandemic that had severely impacted the world was the Spanish flu pandemic of 1918 but the devastation caused by COVID19 is not comparable. Some of the reasons for that could be described as high levels of urbanization and a steep rise in population in the modern world. The Following are some of the reviews of papers on how Covid 19 has affected the global world and the situation during Pandemic and its aftermath. The spread of the virus has encouraged the social distancing which led to the shutdown of educational institutes, markets, offices, conferences and businesses etc. (Peterson et al 2020). The global lockdowns have major interruption on Trade, Business, Schooling, offices and social behavior. According to the United Nations
Educational Scientific Cultural Organization (UNESCO) 192 countries have closed their schools and universities as of April 30, 2020. Over 30 million people have been infected by the coronavirus in India. COVID-19 can infect people of all gender and ages. However, some women and girls may be at higher risk because they are poorer and lack information and resources, or because they are at the front line as caregivers and workers in the health and service sectors. (UN Women 2020) The numerous challenges that governments and societies are facing in tackling the coronavirus, and the threats that the Pandemic has further imposed to globalization and international cooperation, clearly show that the role of science as a response to crisis is limited in face of a socioeconomic disarrangement that increasingly cripples the potential gains of technical action. (Ulisses Barres de Almeida et al 2020) After some serious efforts worldwide including in India the vaccine has been developed to cure from COVID-19 and to protect the no of casualties in future. Globally, as of 5:45pm CEST, 22 October 2021, there have been 242,348,657 confirmed cases of COVID-19, including 4,927,723 deaths, reported to WHO.As of 21 October 2021, a total of 6,655,399,359 vaccine doses have been administered. Looking at the distress occurred by Covid 19 it is Gandhi, who's thoughts and ideas are very -very useful and acceptable in present time.

\section{THE EMERGENCE OF GANDHI'S SOCIAL THOUGHTS}

The young Gandhi read Ruskin's book on a train journey from Johannesburg to Durban in South Africa in June 1904 when he was 34 . He was to confess later that this book changed his life forever. Now he was determined to apply the precepts of Ruskin in his daily life. Barely five years later, in 1909, on a voyage from London to South Africa, Gandhiji penned his Hind Swaraj or Indian Home Rule. This was a trenchant critique of Western civilization, and capitalism in particular. The colonial British government reckoned this to be a seditious piece of work and the pamphlet was banned in British India. Hind Swaraj can be regarded as the social and economic testament of Gandhi. His focus was on those living in the countryside, and he made a strong case to develop rural India as self-sufficient village republics. He essentially believed that all ablebodied men and women must be gainfully employed, and he was against machinery to the extent that it displaced labour.

Historically, globalization is a flight of the development process of human civilization from an isolated socioeconomic formation of primitive society to present satellite 
stage of global interaction of economy and technology across the globe. This term became popular with the process of global economic reforms, i.e., liberalization of provisions of public sector, privatization of public sector and relaxing national restrictions for global interaction. Therefore, it is also known as crossing national boundaries, internationalization, universalization, etc. The excess of internationalization and globalization has resulted crises and pain. Infect Possibly the greatest original insight of Gandhi was to advocate the principle of "limitation of wants". His concern about Frugality was remarkable. He had the quality of being frugal, sparing, thrifty, prudent or economical in the consumption of consumable resources such as food, time or money, and avoiding waste, lavishness or extravagance and he urged the people to include this in daily life practice. The present episode of the pandemic gives us yet another opportunity to revisit Gandhi's critique of Western civilization.

\section{GANDHI'S VISION OF SWADESHI AND GRAM SWARAJ}

Mahatma Gandhi's concept of Gram Swaraj (Village Republic) can be taken and appreciated in the light of the coronavirus pandemic. He used to say that India's soul lives in its villages. To Gandhi, villages were the basic units of social organization. Therefore, the villages should be self-sufficient in the matters of their vital requirements. According to Gandhi, the knowledge of the highest truth is the aim of self-development. Gandhi does not deny the reality of the world here and now; what he rejects is immersion in the phenomenal world, the life of everydayness. He dislikes losing the sense of reality and finds it intolerable. Nor does Gandhi tolerate the development of individuality through willful conquest of others. He underlines the necessity of harmonizing oneself with an ever-enlarging network of relationships that makes society a network of extended selves. Consequently, humanity comes to be located in a highly complex need of inter-dependency, cooperation and harmony. To be an active member of this network is to treat the world as a family (vasudhaiva kutumbakam, वसुधैव कुटुंबकम). In Gandhi's view, truth and non-violence are the necessary foundations of a "global village." Selfless action especially to those who are depressed and deprived nourishes this value. It imparts gradually in man the awareness that one should not have what the poor do not or cannot have. This helps in the minimization of wants and the acceptance of a simple life style that avoids the need for big machines for producing goods and services cutting at the root of industrialization. Instead of the present system of mass production, it would promote production by masses reflecting a heavy reliance on simple technology as well as locally and nationally available resources. Instead of the present system of mass production, it would promote production by masses reflecting a heavy reliance on simple technology as well as locally and nationally available resources. A social order based on truth and non-violence must reflect interdependence conversant by the principle of swadeshi. That is, what Gandhi has expressed, that the most effective organization of social, economic, and political institutions and functions must follow the natural contours of the neighborhood.

The institutional structure of a self-governing society, for Gandhi, must be the local community comprising one or a group of villages that is self-governing democratic republic endowed with necessary powers and authority to manage its own affairs. The village republic must reflect individual freedom informed by social responsibility. Complete decentralization not only in the economic field but also in the political realm must be the basis of village republic, the position of real democracy.

Today, the whole world is struggling to procure basic goods and necessary medical equipment, and hardly a few countries have the stock. Luckily, India has an adequate number of pharmaceutical companies and has made strides in manufacturing and supplies, but it is still dependent on other countries for raw material. This catastrophe has taught us Gandhi's lesson of Self Reliance, a lesson that every country must possess basic amenities for selfsurvival.

Gandhi's principles are very relevant here as it stressed on self-reliance at the local level. Thus, what is needed today is commitment to action on a massive scale, to make opportunities equally good for all. And whatever action is proposed it must be in the Gandhian way, an exercise of moral force. Implementation of the concept of 'Atmanirbhar Bharat' is the real Gandhian way of moving forward in this direction. It's an attempt to increase selfreliance in social life by promoting 'Vocal for Local' and 'Local for Global'. In fact, Gandhi has advocated for a system, in which despite of social diversity, the society should act and grow together. The Constructive Programme as blueprint for the social regeneration of India.

Today, during the catastrophe of pandemic, thousands of poor laborers were forced to migrate to their homes, in such a situation, the importance of Gandhiji's concept of village swaraj and swadeshi is understandable, in which he wanted the youth to stay in the villages for the welfare of their family, society and nation. Serve and become a producer instead of a consumer. Gandhiji believed that villages should produce, prepare their own needs and when 
they met their needs, they should fulfill the needs of the cities. In this way, contribute to each other's progress in the spirit of mutual cooperation. During the Covid 19 and its aftermath these ideas have proved to be very useful as we have realized and experienced the use of Swadeshi and buying goods, daily needs from vendors around us. In fact, what so ever we have achieved during epidemic and lockdown, and having some success in fighting the infection, it is only by adopting the ideas of Mahatma Gandhi and his way of life and methodology. Prime Minister Shri Narendra Modi has also presented selfreliance as the solution to all problems and the goal of a better tomorrow in the critical times of the COVID 19 pandemic.

\section{CONCLUSION}

The COVID-19 crisis not only challenges disease control and crisis management, but also have long-term and farreaching impacts on states, societies and international cooperation. The crisis has upended societies and dramatically altered everyday life across the globe. Our present circumstances, while unprecedented, have been profoundly shaped by persistent societal realities - such as entrenched social and economic inequality, the proliferation of misinformation, and anxieties about the ability of the world's democracies to confront major crises. In-depth social understanding will be critical to apprehending the crisis and charting a path forward.

The current crisis underlines the need of a profound change, although science and technology are not in themselves the solution, they are necessary tools to enable it. There are increasing indications that the world is looking different after the crisis and that globalization is questioned in many areas. According to these observations, the COVID-19 crisis would mark a turning point. The building of a new humanism must be based on a socioeconomic structure where people find the opportunity for an integral development. Such structure should be adopted the thoughts and ideas of Gandhi ji and emphasize the identity of the person, both at the smallest scale, strengthening families and cultural groups, as well as at national level, where cultural identity and tradition are preserved.

Years before Gandhi has given a mantra that whenever we have any doubts or our ego starts dominating us, then we should try this criterion to remember the face of the poorest and weakest man we have seen and ask from our heart what steps should be taken. We are considering how useful it would be to that man. Will it be of any benefit to him?.......that is, will it be able to give Swaraj to crores of people whose stomach is hungry and soul is unsatisfied?
This Jantar of Gandhi is very useful in the circumstances of Covid 19 and its aftermath.

\section{REFERENCES}

[1] Gandhi, M.K., 1927An Autobiography or The Story of My Experiments with Truth, Navajivan Publishing House, Ahmedabad.

[2] Kripalani, J.B., 1971 Gandhi: His Life and Thought, The Publications Division, Ministry of Information and Broadcasting, Government of India, New Delhi.

[3] Mosley Dr Michael, Covid-19 what you need to know about the Coronavirus and the race for the vaccine, Simon \& schuster India.

[4] Young India, 1919-31, Navajivan Publishing House, Ahmedabad.

[5] Gandhi, M.K. The story of my Experiment with truth, Navjivan publication Ahmedabad

[6] CWMG, Vol. VIX, Publication Division, Govt. of India,

[7] Gandhi, M.K, Mangal Prabhat, Navjivan publication Ahmedabad

[8] Gandhi, M.K, Sarvoday, Navjivan publication Ahmedabad

[9] Gandhi ,M.K,1967,Anasaktiyog, Navjivan publication Ahmedabad

[10] Gandhi, M.K,2019, Hind Swaraj,Serva Seva Sangh Publication, Varanasi.

[11] UN Women survey conducted in 2020 in 14 states and 10 urban areas of India as part of a forthcoming report. Retrived through URL https://www.unwomen.org/en/news/stories/2021/7/faqwomen-and-covid-19-in-india? on 19 oct 2021 at 13 :

[12] https://www.hindustantimes.com/analysis/covid-19-thereare-answers-that-lie-in-gandhi-s- $\quad$ hind-swaraj/story5Id3Z3kXhmkz3jGt1FzCvO.html Retrived on 20 oct 2021 at $20: 15$

[13] https://www.hindustantimes.com/analysis/covid-19-thereare-answers-that-lie-in-gandhi-s-hind-swaraj/story5Id3Z3kXhmkz3jGt1FzCvO.html Retrived on 23 oct 2021, $12: 40$

[14] https://www.ncbi.nlm.nih.gov/sars-cov-2/ Retrived on 23 oct 2021 at $12: 45$

[15] Covid-19: There are answers that lie in Gandhi's Hind Swaraj, Retrived through URLhttps://www.hindustantimes.com/analysis/covid-19there-are-answers-that-lie-in-gandhi-s-hind-swaraj/story5Id3Z3kXhmkz3jGt1FzCvO.html on 24 oct 2021, 12:40

[16] https://www.who.int/health-topics/coronavirus\#tab=tab 1 Retrived on 25 oct 2021 at 10:50

[17] https://covid19.who.int/ Retrived on 25 oct 2021 at 16:10

[18] https://www.hindustantimes.com/topic/gandhi-150-years-on Retrived on 25 oct 2021 at 21:14

[19] https://www.cprindia.org/covid-19/timeline Retrived on 25 oct 2021 at $21: 56$

[20] https://www.india.gov.in/spotlight/fight-against-covid-19 Retrived on 25 oct 2021 at 22:46

[21] https://es.scribd.com/document/294288158/03-Gandhi-sSocial-Thought-Nadal Retrived on 25 oct 2021 at 23:34 
[22] https://www.msn.com/en-us/health/medical/chris-rockreveals-he-has-covid-19/aAAOBLR0 Retrived on 25 oct 2021 at 23:36

[23] https://www.researchgate.net/publication/343818298_Lesso ns_from_online_teaching_learning_and_research_communi cations_due_to_COVID-19_related_lockdown Retrived on 25 oct 2021 at $23: 44$

[24] https://www.unwomen.org/en/news/stories/2021/7/faqwomen-and-covid-19-in-india Retrived on 25 oct 2021 at 23:45 